\title{
Micro-credit programmes of different NGOs/MFIs: A comparative study
}

\author{
Mohammad Amirul Islam ${ }^{1}$, M. A. Khatun ${ }^{2}$, D. Hossain ${ }^{3}$ and J. Alom ${ }^{4}$ \\ ${ }^{1}$ Department of Agricultural Statistics, Bangladesh Agricultural University, Mymensingh-2202, Bangladesh, \\ ${ }^{2}$ Department of Agricultural Statistics, Sylhet Agricultural University, Sylhet, ${ }^{3}$ On-Farm Research Division, Bangladesh \\ Agricultural Research Institute, Sylhet and ${ }^{4}$ Uttara Bank Limited, Kishoregonj Branch, Barabazar, Kishoregonj, E- \\ mail:maislam_soton@yahoo.com
}

\begin{abstract}
This study evaluated micro-credit programmes of six leading NGOs/MFIs (BRAC, Grameen Bank, PROSHIKA, ASA, SSS and TMSS) in terms of the clients' views towards the programmes. The objective of this project is to develop a selection criterion to identify the efficient programme. A total of 406 members from the selected NGOs/MFIs operating micro-credit programmes in Dhaka, Mymensingh, Sherpur, Netrokona, Kishoreganj, Norshingdi, Sylhet and Lalmonirhat were interviewed. The data analyses reveal that the majority of the large amount of loans (above Tk.15000) was taken by GB members (33.7 percent). The respondents who knew the actual interest rate were more in BRAC (42.9 percent). Workers of GB ranked first in terms of field visit (24.9 percent). Request needed to get loan was the highest in BRAC (53.0 percent). The satisfaction level of respondents was more in GB and low in SSS. Poverty alleviation due to micro-credit was the highest among GB members (22.0 percent). Logistic regression analysis suggests that amount of loan taken, experience of poverty alleviation and NGO membership are three important determinants of satisfaction level on the micro-credit programme. A set of characteristics were chosen to find out the best performing micro-credit operating NGOs/MFls. The data analysis suggests that TMSS is the best performing NGOs/MFIs. The successive NGOs/MFIs in order of rank are GB, SSS, PROSHIKA, BRAC and ASA, respectively.
\end{abstract}

Keywords: Micro-credit, Client's perception, Efficiency of programme

\section{Introduction}

Micro-credit is seen as an efficient tool for poverty alleviation in rural areas around the globe where formal credit is not available. A large number of studies have been conducted to evaluate the performances of micro-credit programme. While some found positive impacts of microfinance programmes in poor areas of the world (for example, Miller and Martinez, 2006; Stephens and Tazi, 2006; Hossain, 1984; Hossain, 1988; Akter, 1996; Hashemi et al., 1996; Humal and Mosley, 1996; Khandker and Chowdhury, 1996; Ghosh, 1997; Khandker, 1998; Islam, 1999; Uddin, 2000; Jehangir et al., 2002; Pallavi and Ramakumar, 2002; Khandker, 2003; Alam, 2005; Jalil, 2005; Madhura, 2007; Islam, 2009; Parveen and Chaudhury, 2009; Pitt et al., 2003), some found negative impact or lack of impact of micro-credit (for example, Copestake et al., 2001; Morduch, 1998; Dugger, 2004; Coleman, 2001; Buckland, 1996).

Many Non-Government Organisations (NGOs)/Micro Finance Institutes (MFIs) in Bangladesh are running micro-credit programmes in rural Bangladesh. Programme structure, coverage, client type, terms and condition and interest rate vary from programme to programme as well as between NGOs/MFIs. Despite reported success of micro-credit programmes, differences in the programmes will lead to different outcomes. There have been limited accessible studies comparing the similarity and dissimilarity between the programmes run by different NGOs/MFIs. It is important to identify the best practised method for policy purposes as well as for academic interest. Such information will guide the new comers in this sector. Given that micro-credit programmes are widely accepted and worldwide practised method of rural development, no single structure of the programme is yet to be identified as the most efficient to ensure rapid rural development. Moreover, there is a huge criticism of high interest rate. This research aims to address the issues by comparing the micro-credit programme activities of leading NGOs/MFls in this sector. The specific objectives of the project were to i) evaluate the clients' views regarding the credit programmes they are involved with and compare the results between different NGOs and ii) identify the efficient micro-credit programme through development of selection criterion. 


\section{Materials and Methods}

\section{Data}

Members of Bangladesh Rural Advancement Committee (BRAC), Grameen Bank, PROSHIKA, Association for Social Advancement (ASA), Society for Social Service (SSS) and Thengamara Mohila Sabuj Sangha (TMSS) were chosen for the study. Field work was conducted in different locations in Mymensingh, Sherpur, Netrokona, Kishoreganj, Dhaka, Narshingdi, Sylhet and Lalmonirhat where the selected NGOs/MFIs operate their micro-credit programmes. In these eight districts, twenty-seven villages were selected purposively and among these villages, 406 micro-credit clients were chosen randomly for the study (Table 1). The survey was conducted during July 2011- June 2012.

Table 1. Distribution of Respondents According to Districts and Name of NGOs

\begin{tabular}{|l|c|c|l|c|}
\hline Name of Districts & Number of Villages & $\begin{array}{c}\text { Total } \\
\text { Respondents }\end{array}$ & Name of NGOs & Total Respondents \\
\hline Dhaka & 6 & 56 & ASA & 85 \\
\hline Mymensingh & 3 & 126 & BRAC & 86 \\
\hline Sherpur & 5 & 60 & GB & 84 \\
\hline Kishoreganj & 3 & 59 & SSS & 40 \\
\hline Netrokona & 3 & 51 & PROSHIKA & 71 \\
\hline Sylhet & 3 & 20 & TMSS & 40 \\
\hline Lalmonirhat & 3 & 20 & & \\
\hline Narsingdi & 1 & 16 & & \\
\hline & & & & \\
\hline Total & 27 & 406 & Total & \\
\hline
\end{tabular}

\section{Binary Logistic Regression Model}

For a dichotomous dependent variable multiple linear regression modelling is not possible as the assumption that the dependent variable is continuous is violated. In such situation, binary logistic Regression model is a suitable alternative. Let $Y$ be a dichotomous dependent variable, say client's satisfaction with micro-credit programme taking values 1 and 0 and suppose that $Y=1$, if the client is satisfied and $Y=0$, otherwise. Also let $X$ be an independent variable. Then the form of the logistic regression model is

$P=p(Y=1 / X)=\frac{e^{\beta_{0}+\beta_{1} X}}{1+e^{\beta_{0}+\beta_{1} X}}$

and, $1-P=p(Y=0 / X)=\frac{1}{1+e^{\beta_{0}+\beta_{1} X}}$

Then a transformation of $\mathrm{P}$ known as the logit transformation and is defined as

$g(x)=\operatorname{logit} P=\log \left[\frac{P}{1-P}\right]=\beta_{0}+\beta_{1} X$.

For more than one independent variable the model can be generalised as

$g(x)=\operatorname{logit}\left(P_{i j}\right)=\beta_{0 j}+\sum_{l=1}^{k} \beta_{l} x_{i j l}$ 


\section{Comparison between NGOs and MFIs}

A set of characteristics were chosen to categorise the best performing NGO. These were i) if the clients knew actual interest rate, ii) visit by the NGO workers, iii) if any request was needed to get loan, iv) if the client thought that the loan was affordable, $v$ ) if the clients were satisfied, vi) if micro-credit brought any positive change in poverty situation, and vii) if the organogram of the NGO (as a proxy of operating cost) was simple/complex. Each of the NGOs was assigned with a score ranging from 1 to 6 for their ranks of performances for the characteristics considered. The lower the score the better the performance. The lowest aggregate score obtained by the NGO will identify the best performing NGO.

\section{Results and Discussion}

\section{Bi-variate analysis}

Amount of loan was significantly associated with NGOs/MFIs. Most of the respondents took loan within the range of Taka 6000 to 10000 . The majority of respondents who took loan above Tk.15000 were GB members (33.7\%) (Table 2). Most of the respondents did not know the actual interest rate. These types of respondents $(21.6 \%)$ were more in ASA. The respondents who knew the actual interest rate were more in BRAC (42.9\%). Visit of the field workers has significant effect on the membership of different NGOs/MFIs. In GB, the field workers' activities were good (24.9\%) whereas these activities were low in TMSS (10.4\%). In some NGOs/MFIs clients required some type of request to get loan. Most of the clients who needed request to get loan belong to BRAC (53.0\%). Respondents who reported that loan was affordable the highest $20.6 \%$ were members of GB.

Table 2. Cross Tabulation between Important Independent Variables and NGOs/MFIs

\begin{tabular}{|c|c|c|c|c|c|c|c|}
\hline \multirow[t]{2}{*}{ Characteristics } & \multirow[t]{2}{*}{$\mathrm{N}$} & \multicolumn{6}{|c|}{ Name of NGO (\%) } \\
\hline & & ASA & BRAC & GB & SSS & PROSHIKA & TMSS \\
\hline \multicolumn{8}{|c|}{ Amount of loan $(p=.0001)$} \\
\hline $1000-5000$ & 58 & 15.5 & 24.1 & 29.3 & 5.2 & 20.7 & 5.2 \\
\hline $6000-10000$ & 193 & 25.4 & 20.7 & 14.5 & 14.5 & 12.4 & 12.4 \\
\hline $11000-15000$ & 60 & 20.0 & 31.7 & 11.7 & 8.3 & 18.3 & 10.0 \\
\hline Above 15000 & 95 & 15.8 & 13.7 & 33.7 & 4.2 & 25.3 & 7.4 \\
\hline \multicolumn{8}{|c|}{$\begin{array}{l}\text { Know actual interest rate } \\
(p=.0001)\end{array}$} \\
\hline Yes & 63 & 17.5 & 42.9 & 17.5 & 3.2 & 9.5 & 9.5 \\
\hline No & 343 & 21.6 & 17.2 & 21.3 & 11.1 & 19.0 & 9.9 \\
\hline \multicolumn{8}{|c|}{ Visit of field worker $(p=.001)$} \\
\hline Yes & 309 & 16.5 & 20.1 & 24.9 & 11.3 & 16.8 & 10.4 \\
\hline No & 97 & 35.1 & 24.7 & 7.2 & 5.2 & 19.6 & 8.2 \\
\hline \multicolumn{8}{|c|}{$\begin{array}{l}\text { Needed request to get loan } \\
(p=.0001)\end{array}$} \\
\hline Yes & 66 & 25.8 & 53.0 & 3.0 & 13.6 & 3.0 & 1.5 \\
\hline No & 340 & 20.0 & 15.0 & 24.1 & 9.1 & 20.3 & 11.5 \\
\hline \multicolumn{8}{|l|}{ Affordable loan $(p=.074)$} \\
\hline Yes & 248 & 18.1 & 19.4 & 20.6 & 12.9 & 16.1 & 12.9 \\
\hline No & 8 & 25.0 & 25.0 & 12.5 & 12.5 & 25.0 & 0.0 \\
\hline Very difficult & 149 & 25.5 & 23.5 & 21.5 & 4.7 & 19.5 & 5.4 \\
\hline \multicolumn{8}{|c|}{ Satisfaction level $(p=.055)$} \\
\hline Yes & 367 & 20.2 & 19.1 & 21.5 & 9.8 & 18.8 & 10.6 \\
\hline No & 30 & 26.7 & 40.0 & 16.7 & 10.0 & 3.3 & 3.3 \\
\hline Others & 9 & 33.3 & 44.4 & .0 & 11.1 & 11.1 & .0 \\
\hline \multicolumn{8}{|c|}{$\begin{array}{l}\text { Change due to micro-credit } \\
(p=.0001)\end{array}$} \\
\hline Yes & 309 & 13.9 & 19.1 & 22.0 & 11.3 & 21.4 & 12.3 \\
\hline No & 97 & 43.3 & 27.8 & 16.5 & 5.2 & 5.2 & 2.1 \\
\hline
\end{tabular}

Note: $p$-values are based on chi-square tests. Row percentages add up to 100. 
Among the clients who reported difficulty to repay loan 25.5 percent were members of ASA. Respondents satisfied with loan were more in GB (21.5\%) and low in SSS (9.8\%). Most of the respondents improved their poverty situation by using micro-credit loan. This corroborates the findings of other studies (for example, Hossain, 1984; Hossain, 1988; Akter, 1996; Hashemi et al., 1996; Humal and Mosley, 1996; Khandker and Chowdhury, 1996). The highest number of micro-credit clients who were able to change their poverty situation belonged to GB $(22.0 \%)$.

\section{Regression analysis}

Logistic regression analysis suggests that amount of loan taken, experience of poverty alleviation and NGO membership are three important determinants of satisfaction level on the micro-credit programme (Table 3). The analysis suggests that members of BRAC were 0.242 times significantly less likely to be satisfied with the micro-credit programmes than the members of Grameen Bank. Respondents taking loan upto Tk 5000 were 19.6 times significantly more likely to be satisfied with micro-credit than the members taken loan more than Tk 15000. Micro-credit clients who did not have any change in their poverty situation were 0.215 times less likely to be satisfied with micro-credit.

Table 3. Logistic regression estimates of the effects of different independent variables on the satisfaction with the NGO/MFI

\begin{tabular}{|l|c|c|c|}
\hline Independent variable & $\beta$ & SE & Odds ratio \\
\hline NGO/MFI (r: GB) & & & \\
\hline ASA & -0.557 & 0.604 & 0.562 \\
\hline BRAC & $-1.417^{* *}$ & 0.579 & 0.242 \\
\hline SSS & -0.846 & 0.748 & 0.429 \\
\hline PROSHIKA & 0.559 & 0.873 & 1.749 \\
\hline TMSS & 0.464 & 1.140 & 1.590 \\
\hline Amount (Tk) of loan (r:>15000) & & & \\
\hline upto 5000 & $2.976^{* *}$ & 1.108 & 19.602 \\
\hline $6000-10000$ & 0.713 & 0.456 & 2.040 \\
\hline $11000-15000$ & 0.210 & 0.559 & 1.233 \\
\hline & & & \\
\hline Change in poverty situation due to micro-credit (r: yes) & & & \\
\hline No & $-1.537^{* * *}$ & 0.401 & 0.215 \\
\hline & & & \\
\hline Constant & 2.752 & 0.537 & 15.677 \\
\hline
\end{tabular}

Note: Level of significance ${ }^{*} p<0.05,{ }^{* *} p<0.01$

\section{Comparison between NGOs/MFIs}

Performances in different assssment indicators for different NGOs/MFIs were ranked in Table 4. Table 4 reveals that different NGOs/MFIs are performing differently for different assessment indicators. The score for the simplicity of the organogram was judgmental based on the perception of the cost that would be incurred as operating cost (organograms of different NGOs/MFls were compared; not provided in the manuscript). The data analysis suggests that TMSS is the best performing NGO/MFI. The successive NGO/MFI in order of rank are GB, SSS, PROSHIKA, BRAC and ASA. 
Table 4. Scores obtained by NGO/MFI for different assessment indicators

\begin{tabular}{|l|c|c|c|c|c|c|}
\hline Assessment indicators & ASA & BRAC & GB & SSS & PROSHIKA & TMSS \\
\hline Client knows actual interest rate & 6 & 1 & 3 & 6 & 5 & 2 \\
\hline Visit by NGO workers & 4 & 5 & 1 & 2 & 4 & 3 \\
\hline Needed request to get loan & 4 & 6 & 1 & 5 & 3 & 2 \\
\hline Client thinks that loan is affordable & 6 & 4 & 3 & 1.5 & 5 & 1.5 \\
\hline Client is satisfied & 5 & 6 & 3 & 4 & 2 & 1 \\
\hline Micro-credit brought change in poverty & 6 & 5 & 4 & 3 & 2 & 1 \\
\hline Simplicity of organogram & 4 & 6 & 5 & 1 & 3 & 2 \\
\hline Total Score & $\mathbf{3 5}$ & $\mathbf{3 3}$ & $\mathbf{2 0}$ & $\mathbf{2 2 . 5}$ & $\mathbf{2 4}$ & $\mathbf{1 2 . 5}$ \\
\hline Rank & $\mathbf{6}$ & $\mathbf{5}$ & $\mathbf{2}$ & $\mathbf{3}$ & $\mathbf{4}$ & $\mathbf{1}$ \\
\hline
\end{tabular}

\section{Conclusion}

Though the goals of the micro-credit programmes of different NGOs/MFIs are almost similar the implementation and achievements are some what different. This study evaluated the NGOs/MFIs in terms of their field management, clients' perception and change of the poverty situation of the clients. This study set the criteria to find out the efficient micro-credit programme and identified TMSS as the best performing NGO among the selected NGOs/MFIs. This study is the first of its kind and hence limited accessible literature can be compared with the findings of this study. Though the study is not a nationally representative one, the findings can still be generalised and future policies may be formulated. Government can adopt the criteria suggested to identify efficient micro-credit programme.

\section{Acknowledgement}

This study was conducted with the financial support from the Bangladesh Agricultural University Research System, Bangladesh Agricultural University, Mymensimngh-2202, Bangladesh (Project No: 2010/33/BAU). The authors are thankful to BAURES for the support.

\section{References}

Akter, S. 1996. Participation of rural women in credit programmes for poverty alleviation in Bangladesh, Paper presented in regional seminar on, 'Recent changes on the rural economy in Bangladesh,' Jointly organized by the Bangladesh Economic Association and Faculty of Agricultural Economics and Rural Sociology, Bangladesh Agricultural University, Mymensingh. Held on 27 November 1997.

Alam, A.B.M.N. 2005. Rural women in micro-credit programs of poverty alleviation: A study of BRAC in sadar upazila of Netrokona district. Unpublished M.S. thesis, Department of Agricultural Economics (Finance). Bangladesh Agricultural University, Mymensingh.

Buckland, J. 1996. The distributional impact of income-generation programs in Bangladesh. Journal of Development Studies, 3(17), 385-404.

Coleman, B.E. 2001. Measuring impact of microfinance programs. Finance for the poor. Asian Development Bank, December 2001, 2(4), 5-7.

Copestake, James, Bhalotra, Sonia, Johnson and Susan. 2001. Assessing the impact of micro-credit: A Zambian case study. The Journal of Development Studies, 37 (4), 81-100.

Dugger, C.W. 2004. Debate stirs over tiny loans for world's poorest. New York Times.

Ghosh, A.R. 1997. Impact of homestead farming on income and women's development in PROSHIKA programme area in gabtali upazilla of Bogra district. Unpublished M.S Thesis, Department of Agricultural Economics, Bangladesh Agricultural University, Mymensingh.

Hashemi, S.M., Schuler, S.R. and Riley, A.P. 1996. Rural credit programmes and women's empowerment in Bangladesh. WorldDevelopment-Oxford, 24(4), 635-653.

Hossain, M. 1984. Credit for the poor. Research monograph No. 4. Bangladesh Institute of Development Studies, Dhaka.

Hossain, M. 1988. Credit for alleviation of rural poverty: The grameen bank in Bangladesh. IFRI Research Report 65 . International Food Policy Research Institute, Washington, D.C. 
Humal, D. and Mosley, P. 1996. Finance Against Poverty, Volumes 1 and 2, Routledge: London.1996.

Islam, M.R. 2009. Comparative performance of NGO services in a selected area of Mymemsingh district. Unpublished M.S. thesis, Department of Agricultural Economics (Finance). Bangladesh Agricultural University, Mymensingh.

Islam, S. 1999. Micro-credit for the poor: A study of small farmers development project (SFDP) in sadar thana of Bogra district. Unpublished M.S. thesis, Department of Agricultural Economics (Finance). Bangladesh Agricultural University, Mymensingh.

Jalil, M.A. 2005. Impact of micro-credit program of RDRS on rural women in some selected areas of Kurigram district. Unpublished M.S. thesis, Department of Agricultural Economics (Finance). Bangladesh Agricultural University, Mymensingh.

Jehangir, W.A., Ashfaq, M., Ali, A. and Sarwar, N. 2002. Use of credit for poverty reduction by small farmers. International Water Management Institute, Lahore, Pakistan, Pakistan Journal of Applied Sciences, 2(7), 777-780. http://www.pjass.org.

Khandker, S.R. and Chowdhury 1996. Targeted credit programs and rural poverty in Bangladesh. World Bank Discussion Paper 306, Washington, D.C.

Khandker, S. 1998. Fighting Poverty with Micro-credit: Experience in Bangladesh. New York: Oxford University Press for the World Bank.

Khandker, S. 2003. Micro-finance and poverty: Evidence using panel data from Bangladesh. World Bank Policy Research Paper 2945, World Bank, Washington.

Madhura, S. 2007. The microcredit alternative? Economic and Political Weekly, 42 (13), 1171-1175.

Miller, J. and Martinez, R. 2006. "Championship league: An overview of 80 leading latin American providers of microfinance". Microbanking Bulletin, April 2006.

Morduch, J. 1998. Does Microfinance Really Help the Poor? New Evidence From Flagship Programs in Bangladesh. MacArthur Network, Princeton University.

Pallavi, C. and Ramakumar, R. 2002. Micro-credit and rural poverty: An analysis of empirical evidence. Economoc and Political Weekly, 37(10), 955-965.

Parveen, S. and Chaudhury, M.S.R. 2009. Micro-credit intervension and effects on empowerment of rural women: The BRAC experience. Bangladesh Research Publications Journal, ISSN: 1998-2003, 2(3), 641-647.

Pitt, M.M., Khankder S.R., Chowdhury, O.H., Millimet, D.L. 2003. Credit programs for the poor and the health status of children in rural Bangladesh. International Economic Review, 44(1), 87-118.

Stephens, B. and Tazi, H. 2006. Performance and transparency: A survey of microfinance in south Asia. Microbanking Bulletin, April 2006.

Uddin, M.H. 2000. A Study on the impact of grameen bank credit program on rural women beneficiaries in a selected area of Mymensingh district. Unpublished M.S. thesis, Department of Agricultural Economics (Finance). Bangladesh Agricultural University, Mymensingh. 